\title{
The Problems and Countermeasures for Construction Site Quality Management of Industrial and Civil Construction Engineering
}

\author{
Boju Chai \\ Bowen College of Management, Guilin University of Technology, Guilin 541006, China; \\ chaiboju@sina.com
}

Keywords: Industrial and civil construction, Construction site, Quality management

\begin{abstract}
The key process of industrial and civil building construction aim at good engineering quality management. Excellent construction project cannot be separated from the efficient quality management control. The construction environment become more complex and difficult because of the requirement of improved construction quality from people. Therefore, thequality management of construction site appear to be particularly important, and we should actively take effective measures to solve the arisenproblems during the whole process.
\end{abstract}

\section{Introduction}

Quality management of industrial and civil building construction is a special complex system project, all departments andthe person who participates in the project construction should carry outmutual cooperation and close coordination, at the same time good quality control of materials and quality management during the construction process can ensurefavorable development of the industry and civil construction industry[1].

\section{Overview of industrial and civil building construction site quality management}

Management of construction personnel.Management Construction personnel mainly include the selection of related personnel, professions, personnel education and training. After winning the bid for the project, the selection of personnel should be implemented according to the realistic status, then set up the relevant departments and perform reasonable job assignments according to the individual's professional skills.

Management of construction materials. We must make sure the quality of construction materials is good so that the quality of the project can be toassured.We must control the quality of construction materials throughout the entire project process. We need to control the purchase of raw materials, select the most appropriate supply of raw materials manufacturers by a series of contrast,so that the purchase effect canreach the best and cheapest one. At the same time, the transportation and management of raw materials should be further strengthened in the delivery and management,avoiding the damage.

Management of construction equipment.From now on, large machinery and equipment are widely used in the building operations because of the improvedmechanization level. Therefore, we need to focus on the construction quality management of construction equipment management site. We need to implement the actual situation of the project constructionto schedule, construction machinery allocation, in order to ensure the construction at the same time pay attention to saving the project cost. The state of construction machinery and equipment in this process need to be good mastered, in order to avoid safety hazard in the whole construction process.

\section{Problems of industrial and civil construction engineering construction site quality management}

Problems of construction personnel quality.Some relevant management personnel are lack in safety awareness, or someone have the understanding consciousness, but their action is insufficient, so that they often neglect the safety work in the field in site management.Construction staff cannot 
reach the standard of professional skills because of lack of formal training, which leading to their positions cannot be fully qualified. Some people do not follow the rules of the implementation of the operation, but only by the experience, so that often make mistakes, and the quality of the construction is reduced badly.Another key factor is the lake of the ability to deal with realistic problems and on-site response[2].

Distempered site construction management system. There are no clear division of responsibility system in most construction site in our country, not so strict rewards and punishmentsinstitution.Although some sites strictly follow the rules and regulations on the surface, but it is only a mere flow, the results obtained are not so noticeable. China's construction production methods are not put in place, cannot be implemented; team inspection and the company's security inspection cannot be organically combined, the entire construction security system is relatively weak. Some the projects found to have the potential safety hazard but not only is not be implemented the rectification, butit is getting worse and worse, completely ignoring thesupervisor's supervisionand management.

Unreasonable design of time limit for the project.In order to seek short-term interest,some construction enterprisesshorten the project periodartificially, purchasing raw materials and design building construction at the same time.Under these circumstances, each type of work is in the middle of cross operation, the implementation of a long construction, greatly shorten the time limit.Some hundreds of millions construction project is completed using the day and night construction method, the duration reduced to a few months which originally should take several years, illegal construction work also often appear in order to meet the inspection.

\section{Countermeasures for industrial and civil construction engineering construction site quality management}

\section{Basic principles.}

(1) Scientific and reasonable principle

Construction site is complex, we should do specific managementin the management of the workbased on the actual situation, develop a reasonable operation flow, introduce advanced management technology and management methods, improve the utilization of resources, which will make the management more scientific.

(2) Standardization principles

This is the most basic needs of the construction site management. In order to effectively coordinate the entire construction project, a lot of elements in the construction site must be determined to comply with a unified will, subjective randomnessshould be overcome. Only in this way can we work efficiency and management efficiency,start from the foundation of the construction site production, thus build up a scientific and standard field work order.

Proper arrangement of construction schedule.Schedule control of construction project means to implement an appropriate and feasible schedule for the total target before the constructionproject. We should predict the progress of the division and think about some possible causes which may have bad impact on the construction. Only by this way can we avoid the rapid quality construction of the project in order to catch up with the project.Also we should appropriately preparethe project schedulein accordance with the requirements of the contract. If we want to get good civil engineering and installation, we must let all the construction personnel and installation personnel to participate in the progress plan, coordinate the relevant staff, machine equipment and application materials according to the scheduleto ensure the completion of the total target.

Strengthen the quality control.Firstly, we should carefully implement the drawings. Construction drawings embodies a lot of hard work of the design personnel, they must be carefully implemented and give a comprehensive review, from the plane, elevation, section to the construction of a large sample, from each layer of the reinforcement structure chart, system related to the control and responsible, not clear, doubt and not appropriate place to record, merged with the designers, construction enterprises and construction party leadership together with the implementation of detailed triage and drawings for the implementation of necessary brainstorming 
and correction, for the successful construction and lay a solid foundation for the implementation of the. Second, carefully review the construction team before the start of the construction organization design. To determine the key construction scheme and method, to develop the construction schedule, the specific calculation of construction machinery, labor consumption, the amount of key materials,the design of the general layout of the construction plan. For the project is relatively complex, high technical requirements, construction difficulty, as the site management personnel on the program to carefully review, the construction method and the program to make the necessary changes, so that the project construction in accordance with the implementation of the project, to ensure the construction progress and project quality.

Strengthen safety management to ensure the constructionquality.Construct the security officer"three unified" system and the security of the security staff liaison system, fully display the function of the security staff.Unified by the higher authorities in charge of the security staff to send a unified system of security, the higher authorities in charge of unified payment of wages and benefits, by the higher authorities in charge of the unified development of work responsibilities. This is the support for the enterprise to the security staff, so that the security staff will not be controlled by the project manager or project contractor.

Enhance the safety diatheses of the workers, construct safety training system. Workers can get qualification certificates only after the safety training. According to this rules, the new workers enter into the construction site must hold a safety qualification certificate, otherwise they are not allowed to enter into the construction site.

\section{Conclusion}

From the above summary we can draw a conclusion that if we want to get the clearance of the project quality, not only excellent mechanical equipmentareneeded, but also strictly materials control is important and excellent management practices, etc., only in this way can we have a guarantee of quality. Through the quality management of the industrial and civil construction, we can reduce the construction cost, improve the construction quality andfinally create a good economic benefitsfor the enterprise [3].

\section{References}

[1] Wang F X. Study on the management of industrial and civil building engineering [J]. Market Research, 2012,(02) .

[2] Tong Y C. On the quality management of the construction site in the industry and civil construction[J].Chinese Real Estate Industry, 2012, 23(3): 159-161.

[3] Liu X S. Strengthen the construction site management level to improve the quality of construction projects[J]. Management and Technology of Small and Medium Sized Enterprises, 2011(33). 